\title{
Characteristics and Electrical Parameters of Silicon Nanowires (SiNWs) Solar Nanocells
}

\author{
M. Hebali1,2,*, M. Bennaoum ${ }^{1}$, H.A. Azzeddine ${ }^{1}$, B. Ibari ${ }^{1}$, M. Benzohra ${ }^{3}$, D. Chalabi ${ }^{2}$ \\ ${ }^{1}$ Department of Electrotechnical, University Mustapha STAMBOULI Mascara, 29000 Mascara, Algeria \\ ${ }^{2}$ Laboratory CaSiCCe, ENP Oran-MA, 31000 Oran, Algeria \\ ${ }^{3}$ Department of Networking and Telecommunications, University of Rouen, Laboratory LECAP, 76000, France
}

(Received 13 June 2020; revised manuscript received 21 December 2020; published online 25 December 2020)

\begin{abstract}
Silicon nanowires (SiNWs) solar cells are becoming an important axis of scientific research especially in the field of new technologies for photovoltaic energy. In this paper, static characteristics $(I-V, P$ - $V)$ and different electrical parameters $\left(I_{S C}, V_{O C}, I_{\max }, V_{\max }, P_{\max }\right.$ and FF) of the SiNWs solar nanocell are studied according to the number of nanowires $(n)$ at room temperature and under global (AM1.5G) illumination spectra using 2D-Atlas SILVACO software. The simulation results show that the silicon nanowires (SiNWs) solar nanocell is characterized by good electrical characteristics and high performance. Increasing the number of nanowires is a good technique for improving the behavior and electrical performance of the SiNWs solar cells.
\end{abstract}

Keywords: Silicon, Solar nanocell, Silicon nanowires (SiNWs), Static characteristic, Electrical parameters.

DOI: 10.21272/jnep.12(6).06033

PACS number: 81.07.Gf

\section{INTRODUCTION}

The photovoltaic energy is considered one of the most important of renewable energies [1,2], as this energy is obtained by converting sunlight into electricity using solar cells. The photovoltaic effect was discovered in 1839 by the French physicist Edmond Becquerel when he noticed the change in voltage of a platinum electrode under the effect of illumination with light [3]. In recent years, solar energy has been able to attract increased attention by exploiting it in various fields $[4,5]$. The concepts of nanotechnology have addressed different areas of science and technology in the last decade [6], the most important of these areas is photovoltaic conversion $[7,8]$. So that several recent researches have focused on the study of solar cells in micro- and nanotechnology [9-11], especially in nanowires (NWs) solar cells, so that this technology has contributed to the improvement of the different electrical parameters and conversion efficiency of these cells [12-14].

In this work, we will study the electrical behavior of the silicon nanowires (SiNWs) solar nanocell. To carry out a good study of this cell, we will study the effect of the number of nanowires $(n)$ on the different characteristics and important parameters that define the electrical performance of the solar cell. To realize this study, we will present the structure of this cell according to the different dimensions and doping technologies. Then, on the basis of the structure of the SiNWs solar nanocell, we will simulate its characteristics such as current-voltage $(I-V)$ and powervoltage $(P-V)$ according to the number of nanowires $(n=1,2,3,4,5)$ at room temperature and under global (AM1.5G) illumination spectra. We will exploit these characteristics to find the electrical parameters of our cell such as short-circuit current $\left(I_{S C}\right)$, open-circuit voltage $\left(V_{O C}\right)$, maximum voltage $\left(V_{\max }\right)$, maximum current $\left(I_{\max }\right)$, maximum power $\left(P_{\max }\right)$ and fill factor (FF). We will use in this study the 2D-Atlas SILVACO software as a simulation tool.

\section{SiNWs SOLAR NANOCELL STRUCTURE}

Fig. 1 shows the structure of the silicon nanowires (SiNWs) solar nanocell. Each nanowire in this cell con-

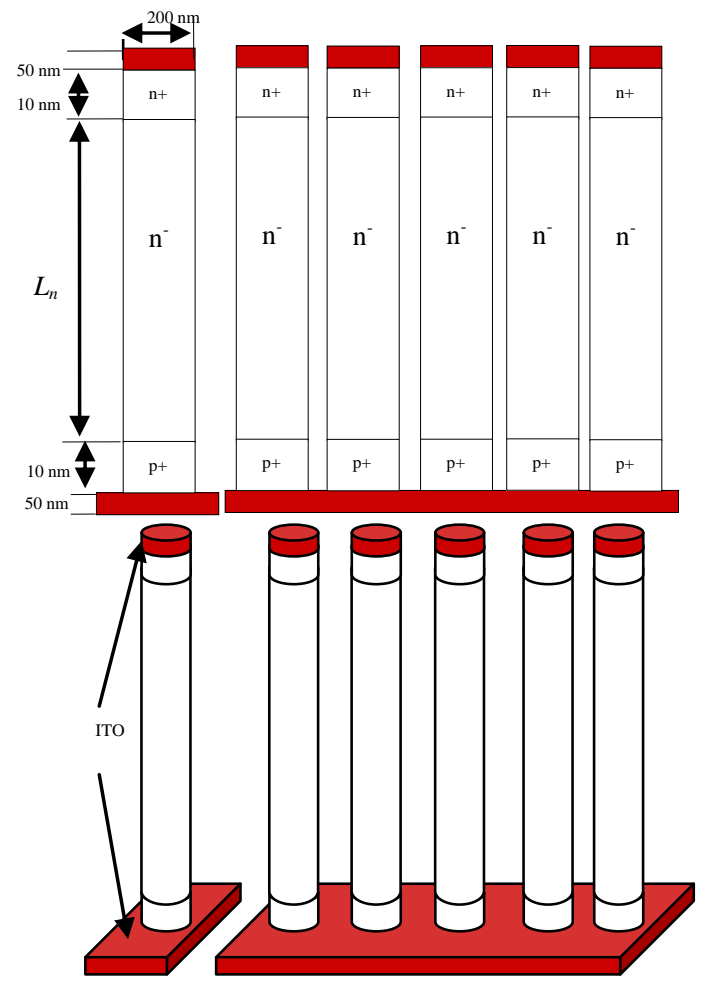

Fig. 1 - Silicon nanowires (SiNWs) solar nanocell structure proposed

*mourad.hebali@univ-mascara.dz 
tains a silicon layer without thickness defects. This layer is deposited on the electrode of indium oxide and tin (ITO) (cathode). On the silicon layer, there is the second electrode (anode) of the same material. The thickness of the electrodes is the same $T_{\text {ITO }}=50 \mathrm{~nm}$.

Doping of the adjacent areas of the anode and cathode electrodes are $p$ - and $n$-types, respectively, with the same concentration of $1 \cdot \mathrm{E}^{18} \mathrm{~cm}^{-3}$ and the same thickness of $10 \mathrm{~nm}$. The remaining area $\left(L_{n}\right)$ is characterized by $n$-type doping with the concentration of $1 \cdot \mathrm{E}^{14} \mathrm{~cm}^{-3}$. The length and width of this nanowire are $1 \mu \mathrm{m}$ and $200 \mathrm{~nm}$, respectively.

\section{RESULTS AND DISCUSSION}

\subsection{I-V Characteristic}

Fig. 2 shows the evolution of the $I-V$ characteristic of the SiNWs solar nanocell for a different number of nanowires from $n=1$ to $n=5$ under lighting and at room temperature. For this characteristic, the voltage is varied from 0 to $1.2 \mathrm{~V}$.

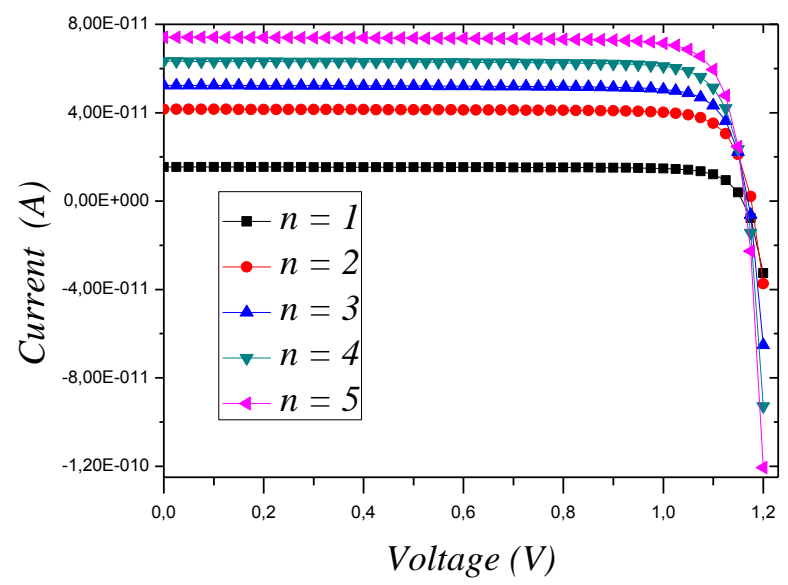

Fig. $2-I-V$ characteristic of the SiNWs solar nanocell

For a solar cell, $I-V$ characteristic is described by the Shockley equation as follows:

$$
I=I_{p h}-I_{S}\left(e^{\frac{q V}{A K_{B} T}}-1\right)
$$

where $I_{p h}$ is the photogenerated current, $I_{S}$ is the saturation current of the diode, $q$ is the electron charge, $V$ is the voltage on the terminals of the cell, $A$ is the ideality factor, $K_{B}$ is the Boltzmann constant and $T$ is the absolute temperature.

In the case of lighting, the SiNWs solar nanocell absorbs sunlight. The photogenerated current $I_{p h}$ (short-circuit current $I_{S C}$ ) of the solar cell is closely related to the incident photon flux on the cell [15]. This phenomenon increases the short-circuit current $I_{S C}$ as shown in Fig. 2. The results of this characteristic (I-V) show that the silicon nanowires (SiNWs) solar nanocell proposed in this work is correctly working according to the operating principle of the PV cells.

$I-V$ characteristic is exploited to draw the Fig. 3. This figure shows the effect of the number of nanowires (n) on the short-circuit current $I_{S C}$ of our SiNWs solar nanocell.

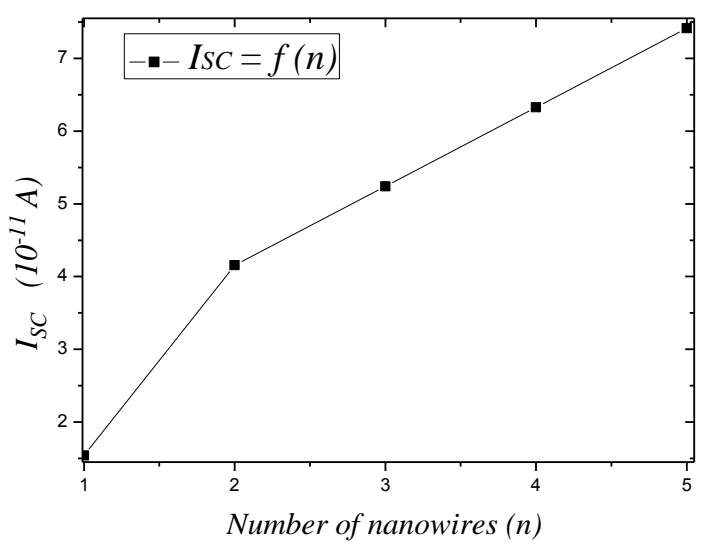

Fig. $3-I_{S C}$ as a function of the number of nanowires $(n)$

The simulation results show that the short-circuit current $I_{S C}$ of the SiNWs solar nanocell is directly proportional to the number of nanowires $(n)$ as shown in Fig. 3.

In the SiNWs solar nanocell, when the number of nanowires increases, the contact surface of this cell with light increases significantly. This leads to an increase in the absorption of light by the nanocell. This causes an increase in the concentration of electron-hole pairs produced, the latter increases the short-circuit current $I_{S C}$ of this nanocell. This necessarily leads to improved energy conversion efficiency and performance of the SiNWs solar nanocell.

\subsection{P-V Characteristic}

$I-V$ characteristic of the SiNWs solar nanocell is exploited to find the $P-V$ characteristic. Fig. 4 shows the evolution of the power as a function of the voltage of the SiNWs solar nanocell for different number of nanowires $n=1$ to $n=5$.

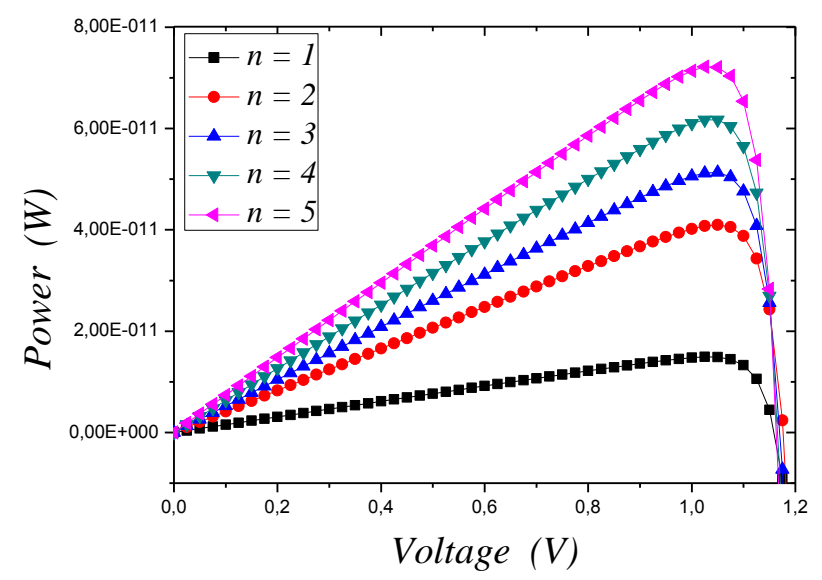

Fig. $4-P$ - $V$ characteristic of the SiNWs solar nanocell

The $P-V$ characteristic of the SiNWs solar nanocell shows that the power of this cell is increased with the increase in the number of nanowires $(n)$ as shown in Fig. 4. This figure is exploited to find the evolution of the maximum power $P_{\max }$ as a function of the number of nanowires $(n)$ of the SiNWs solar nanocell as shown in Fig. 5. 


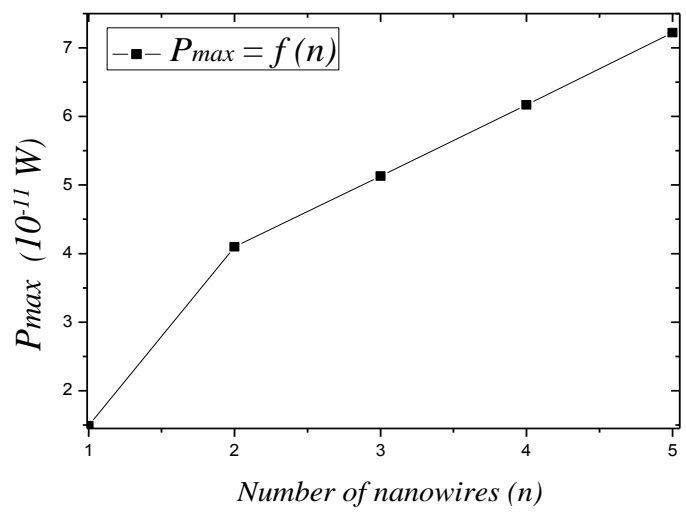

Fig. $5-P_{\max }$ as a function of the number of nanowires $(n)$

The results show that the maximum current $I_{\max }$ is increased as the number of nanowires $(n)$ increases. However, the maximum voltage $V_{\max }$ is not significantly affected by the variation in the number of nanowires (n) for the SiNWs solar nanocell. From the following power relation:

$$
P_{\max }=I_{\max } \cdot V_{\max } .
$$

Therefore, the maximum power $P_{\max }$ is directly proportional to the variation of the number of nanowires (n) for the SiNWs solar nanocell as shown in Fig. 5.

The different static characteristics $(I-V$ and $P-V)$ are exploited to find the Table 1. This table presents the main electrical parameters of the silicon nanowires (SiNWs) solar nanocell. Among the most important of these parameters is the fill factor (FF) given by the following relationship:

$$
\mathrm{FF}=\frac{P_{\max }}{I_{S C} V_{O C}} .
$$

Since the fill factor is a factor that defines the ideality of solar cells [11] and from Table 1, then the silicon nanowires (SiNWs) solar nanocell can be considered as an ideal cell, because the value of the fill factor (FF) is roughly of the order of $84 \%$ for the different values of the number of nanowires $(n)$.

\section{REFERENCES}

1. Mehreen Gul, Yash Kotak, Tariq Muneer, Energy Exploration \& Exploitation 34 No 4, 485 (2016).

2. Farzaneh Fadakar Masouleh, Narottam Das, Seyed Mohammad Rozati, Energies 9, 756 (2016).

3. Paul Hersch, Kenneth Zweibel, Basic Photovoltaic Principles and Methods. First Edition (Technical Information Office, National Renewable Energy Laboratory, USA: 1982).

4. H.A. Azzeddine, M. Tioursi, D. Chaouch, B. Khiari, Revue Roumaine des Sciences Techniques série Electrotechnique et Energétique. 6, 3 (2016).

5. H.A. Azzeddine, M. Tioursi. D. Chaouch, Acta Electrotechnica 54, 6 (2013).

6. Daniel Lincot, Ludovic Escoubas, Jean François Guillemoles, Jean-Jacques Simon et Abdelilah Slaoui, https://www.funmooc.fr/c4x/uved/34004/asset/Nanomateriaux Lincot_2013.pdf.

7. V.K. Sethi, Mukesh Pandey, Priti Shukla, Int. J. Chem. Eng. Appl. 2 No 2, 77 (2011).

8. Z. Abdin, M.A. Alim, R. Saidur, M.R. Islam, W. Rashmi, S. Mekhilef, A. Wadi, Renew. Sustain. Energy Rev. 26, 837 (2013).
Table 1 - Electrical parameters of the SiNWs solar nanocell

\begin{tabular}{|c|c|c|c|c|}
\hline $\begin{array}{c}\text { Parameters } \\
n\end{array}$ & $\begin{array}{c}V_{O C} \\
(\mathrm{~V})\end{array}$ & $\begin{array}{c}I_{\max } \\
\left(10^{-11} \mathrm{~A}\right)\end{array}$ & $\begin{array}{c}V_{\max } \\
(\mathrm{V})\end{array}$ & $\begin{array}{c}\mathrm{FF} \\
(\%)\end{array}$ \\
\hline 1 & 1.1625 & 1.42 & 1.05 & 83.2 \\
\hline 2 & 1.1875 & 3.90 & 1.05 & 83.1 \\
\hline 3 & 1.1625 & 4.89 & 1.05 & 84.2 \\
\hline 4 & 1.1625 & 5.88 & 1.05 & 83.9 \\
\hline 5 & 1.1625 & 7.04 & 1.025 & 83.8 \\
\hline
\end{tabular}

The simulation results show that the short-circuit current $I_{S C}$ and the maximum current $I_{\max }$ are considerably influenced by the variation of the number of nanowires $(n)$. On the other hand, the open-circuit voltage $V_{O C}$ and the maximum voltage $V_{\max }$ remain approximately constant. The fact that the open-circuit voltage and maximum voltage are not affected by the change in the number of nanowires is due to the parallel connection of these nanowires. As for the fill factor (FF), one cannot judge the evolution of this factor as a function of the number of nanowires $(n)$. But the optimal value of this factor of $84.2 \%$ corresponds to the number of nanowires $n=3$ as shown in Table 1 .

\section{CONCLUSIONS}

Electrical performance of the silicon nanowires (SiNWs) solar nanocell is investigated according to the number of nanowires (n) using $I-V$ and $P-V$ characteristics. The electrical parameters of interest are short-circuit current $\left(I_{S C}\right)$, open- circuit voltage (VOC), maximum voltage $\left(V_{\max }\right)$, maximum current $\left(I_{\max }\right)$, maximum power $\left(P_{\max }\right)$ and fill factor $(\mathrm{FF})$. The different static characteristics and electrical parameters of this nanocell are affected by the number of nanowires. The increase in the number of nanowires leads to an increase in the short-circuit current and the power of this cell due to increased absorption surface. The electrical behavior of the SiNWs solar nanocell was also improved by the increase in the number of nanowires, which necessarily leads to the increase in the performance of this cell.

9. Arthur J. Nozik, Nano Lett. 10, 2735 (2010).

10. Eshwar Reddy Cholleti, Md. Akhtar Khan, Mater. Today: Proc. 4 No 8, 7694 (2017).

11. Mourad Hebali, Mohammed Barka, Abdelkader Baghdad Bey, Miloud Abboun Abid, Mohammed Benzohra, Djilali Chalabi, Abdelkader Saïdane, ICTACT Journal on Microelectronics 3, 4 (2018).

12. Guoliang Ma, Rui Du, Ya-nan Cai, Cen Shen, Xudan Gao, Yiheng Zhang, Feng Liu, Wangzhou Shi, Weijie Du, Yiwen Zhang, Sol. Energy Mater. Sol. C. 193, 163 (2019).

13. O.V. Pylypova, A.A. Evtukh, P.V. Parfenyuk, I.I. Ivanov, I.M. Korobchuk, O.O. Havryliuk, O.Yu. Semchuk, Opto-Electron Rev. 27, 2 (2019).

14. Mihir Kumar Sahoo, Paresh Kale, J. Materiomics 5, 34 (2019).

15. Svetlana Pelemiš, Igor Hut, Nanotechnology Materials for Solar Energy Conversion. Contemporary Materials (Renewable Energy Sources) IV-2, 145 (2013). 


\section{Характеристики та електричні параметри сонячних наноелементів з кремніевих нанодротів (SiNWs)}

M. Hebali1,2, M. Bennaoum ${ }^{1}$, H.A. Azzeddine' ${ }^{1}$, B. Ibari1, M. Benzohra ${ }^{3}$, D. Chalabi²

${ }^{1}$ Department of Electrotechnical, University Mustapha STAMBOULI Mascara, 29000 Mascara, Algeria

${ }^{2}$ Laboratory CaSiCCe, ENP Oran-MA, 31000 Oran, Algeria

${ }^{3}$ Department of Networking and Telecommunications, University of Rouen, Laboratory LECAP, 76000, France

Сонячні елементи 3 кремніевих нанодротів (SiNWs) стають важливим напрямом наукових досліджень, особливо в галузі нових технологій у фотоелектричній енергетищі. У роботі вивчаються статичні характеристики (I-V, P-V) та різні електричні параметри (ISC, VOC, Imax, Vmax, Pmax та FF) сонячного наноелементу 3 SiNWs в залежності від кількості нанодротів (n) при кімнатній температурі та під дією глобальних (AM1.5G) спектрів освітлення за допомогою програмного забезпечення 2D-Atlas SILVACO. Результати моделювання показують, що сонячний елемент 3 кремнієвих нанодротів (SiNWs) характеризуеться гарними електричними характеристиками та високою продуктивністю. Збільшення кількості нанодротів - це хороша технологія для поліпшення поведінки та електричних характеристик сонячних елементів з SiNWs.

Ключові слова: Кремній, Сонячний наноелемент, Кремнієві нанодроти (SiNWs), Статична характеристика, Електричні параметри. 